\title{
PENGARUH PENGGUNAAN STRATEGI QUANTUM LEARNING TERHADAP KEMAMPUAN SISWA DALAM SPEAKING
}

\author{
Resty Wahyuni \\ Surel : Resty_shenie@yahoo.com
}

\begin{abstract}
ABSTRAK
Penelitian ini bertujuan untuk mendeskripsikan kemampuan mahasiswa dalam hal keterampilan berbicara dengan menggunakan Strategi Quantum Learning. Dari hasil penelitian dapat dilihat dari 72 orang siswa, dalam mendeskripsikan hasil penelitian ini, peneliti membagi dalam 3 tahap yaitu: Deskripsi hasil perhitungan kemampuan berbicara mahasiswa fakultas keguruan dan ilmu pendidikan jurusan bahasa Inggris tanpa strategi Quantum Learning. Deskripsi hasil perhitungan kemampuan berbicara mahasiswa fakultas keguruan dan ilmu pendidikan jurusan bahasa Inggris dengan menggunakan strategi Quantum Learning. Deskripsi hasil hubungan antara pengaruh penggunaan strategi Quantum Learning terhadap kemampuan berbicara mahasiswa FKIP jurusan bahasa Inggris.
\end{abstract}

Kata Kunci: Pengaruh, Pembelajaran, Strategi, Prestasi, Berbicara, Quantum

\section{PENDAHULUAN}

Keterampilan berbahasa ada
empat yang setiap saat dikembangkan dari tingkat Sekolah Dasar hingga tingkat yang lebih tinggi yaitu tingkat Universitas. Keterampilan tersebut yaitu keterampilan membaca, berbicara, menyimak dan keterampilan menulis. Ketika menerapkan keterampilan tersebut, guru atau dosen menggunakan model, metode, strategi atau teknik yang berbeda.

Persoalan menggunakan metode, model atau strategi pembelajaran yang tepat adalah persoalan yang sering dibahas para guru, dosen atau calon guru, karena metode adalah salah satu komponen yang penting dalam menciptakan proses pembelajaran dikelas. Dalam proses belajar mengajar sering dosen dan guru mendapat kesulitan mencari metode atau model yang tepat untuk disajikan pada kegiatan belajar mengajar. Selain itu dosen dan guru juga sering menggunakan metode konvensional, hal ini membuat siswa bosan dan tidak berminat belajar. Akibatnya hasil pembelajaran tidak tercapai. Salah satu contoh masalah yang dihadapi peneliti yaitu metode atau strategi yang tepat diterapkan di perguruan tinggi dalam mengembangkan minat belajar mahasiswa dalam speaking.

$$
\text { Keterampilan berbicara }
$$
sebagai salah satu aspek sangat penting dalam berkomunikasi secara lisan, harus dikuasai betul - betul oleh para siswa karena jika kurang terampil berbicara, maka komunikasi tidak akan berjalan dengan lancar. Berbicara dalam bahasa inggris berbeda dengan berbicara dalam bahasa indonesia karena bahasa inggris adalah bahasa asing.

$$
\text { Speaking merupakan }
$$

kemampuan yang paling penting dalam bahasa inggris untuk 
dikembangkan di dalam kelas. Di dalam mata kuliah speaking, mahasiswa diharapkan untuk dapat menikmati materi yang diberikan langsung kepada mereka. Seseorang yang dikatakan mampu berbahasa inggris yang aktif apabila ia memiliki keempat skill dalam bahasa.

Orang - orang belajar bahasa asing dengan berbagai alasan, dan salah satu diantaranya adalah komunikasi. Alasan lain, karena keberagaman manusia di dunia seperti perbedaan budaya dan bahasa. Setiap orang harus saling mengetahui satu sama lainnya, hal ini dapat terjadi dengan adanya komunikasi.

Di zaman modern, komunikasi sebagai bahasa kedua memiliki peranan yang penting. Semua hal menggunakan bahasa inggris sebagai petunjuknya, seperti teknologi, ekonomi, bahkan pendidikan. Banyak cara yang dapat dilakukan untuk meningkatkan kemampuan siswa berbicara bahasa inggris anatara lain dengan cara: debat, diskusi, percakapan, story telling.

Berdasarkan penjelasan
diatas untuk meningkatan
keterampilan berbahasa, peneliti
tertarik membahas salah satu
masalah pengembangan strategi
pembelajaran speaking di Perguruan
Tinggi. Dalam hal ini yang
mendorong peneliti berminat
meneliti tentang inovasi strategi
pembelajaran speaking.

\section{METODE PENELITIAN}

Penelitian ini dilakukan di Universitas Muhammadiyah Sumatera Utara Fakultas Keguruan dan Ilmu Pendidikan Semester IV tahun akademik 2016 - 2017, Jalan Kapten Muchtar Basri, Medan. Populasi dari penelitian ini adalah mahasiswa Fakultas Keguruan dan Ilmu Pendidikan Jurusan Bahasa Inggris Tahun Pelajaran 2016 - 2017 yang berjumlah 286 orang. Sampel adalah sebagian dari populasi yang memiliki karakteristik dasar yang dapat mewakili populasi tersebut. Dalam pengambilan sampel, peneliti didasarkan atas pendapat Arikunto (1993 : 107) yang mengatakan "Apabila jumlah sampel lebih dari 100 orang maka diambil persentase $10-15 \%$ atau $20-25 \%$. Karena jumlah populasi 286 orang, maka penulis menetapkan sampel berjumlah 72 orang yang terdiri dari dua kelas.

\section{Prosedur Penelitian}

Surakhmad (1982 : 131) menyatakan "metode merupakan cara yang utama untuk mencapai tujuan, misalnya untuk menguji serangkaian dengan mempergunakan teknik, serta alat - alat tertentu. Cara utama itu digunakan setelah penyelidikkan serta situasi penyelidikkan".

$$
\text { Sesuai dengan tujuan }
$$
penelitian maka metode yang digunakan adalah metode eksperimen yaitu metide penelitian yang dilakukan dengan mengadakan pengamatan secara teliti terhadap 
objek penelitian serta adanya kontrol terhadap objek penelitian tersebut. Variabel kontrol maksutnya adalah variabel yang digunakan sebagai bandingan terhadap variabel yang diteliti, yaitu hasil tes kemampuan berbicara mahasiswa dengan menggunkan startegi Quantum learning .

Didalam

penelitian, eksperimen sampel dibagi dua kelompok yaitu kelompok kelas eksperimen dan kelompok kelas kontrol. Pada kelas eksperimen akan diajarkan speaking dengan menggunakan strategi Quantum learning didalam proses pembelajran. Sebelum proses pembelajaran berlangsung kedua kelompok ini akan diberi pre - test mempraktikkan percakapan (speaking). Pre test dilakukan untuk mengukur kemampuan siswa sebelum diberikan post - test agar dapat melihat hasil kemampuan siswa yang telah diberi treatment.

\section{Teknik Analisa Data}

Setelah data - data diperoleh maka sebelumnya terlebih dahulu dilakukan uji prasyaratan analisis yaitu uji normalitas dan uji homogenitas. Uji normalitas data dilakukan untuk mengetahui apakah data yang diperoleh dari populasi yang berdistribusi normal atau tidak perhitungan dengan menggunakan rumus lilifors. Dan uji homogenitas dilakukan untuk menguji variasi dari populasi homogen, uji normalitas dilakukan untuk mengetahui apakah data yang diperoleh homogen atau tidak terhadap dua kelompok perlakuan. Uji homogenitas dihitung dengan menggunakan rumus fisher, setelah dilakukan perhitungan normalitas dan homogenitas maka dilakukan analisis data untuk menguji hipotesis yang telah diajukan, uji ini dilakukan untuk mengetahui ada tidaknya perbedaan yang signifikan antara mahasiswa yang dberi perlakuan teknik jigsaw dengan perlakuan teknik STAD.

Teknik yang digunakan dalam menganalisis data penelitian ini adalah teknik analisis data deskriptif dan inferensial. Statistic inferensial diarahkan untuk uji hipotesis. Rumus yang digunakan adalah Uji t.

\section{HASIL PENELITIAN DAN PEMBAHASAN}

Sebagaimana telah dikemukukakan pada bagian metode penelitian, bahwa alat yang digunakan dalam mengumpulkan data adalah melalui tes. Dalam mendeskripsikan hasil penelitian ini, peneliti membaginya kedalam tiga tahapan pengelolaan data, yaitu :

a. Deskripsi hasil perhitungan kemampuan berbicara mahasiswa fakultas keguruan dan ilmu pendidikan jurusan bahasa Inggris TA 2016 - 2017 tanpa strategi Quantum learning.

b. Deskripsi hasil perhitungan kemampuan berbicara mahasiswa fakultas keguruan dan ilmu pendidikan jurusan bahasa Inggris TA 2016 - 2017 
Resty Wahyuni : Pengaruh Penggunaan Strategi ...

\section{dengan menggunakan strategi Quantum learning. \\ c. Deskripsi hasil hubungan antara pengaruh penggunaan strategi Quantum Learning terhadap kemampuan berbicara mahasiswa FKIP jurusan bahasa Inggris TA 2016 - 2017}

\section{SIMPULAN}

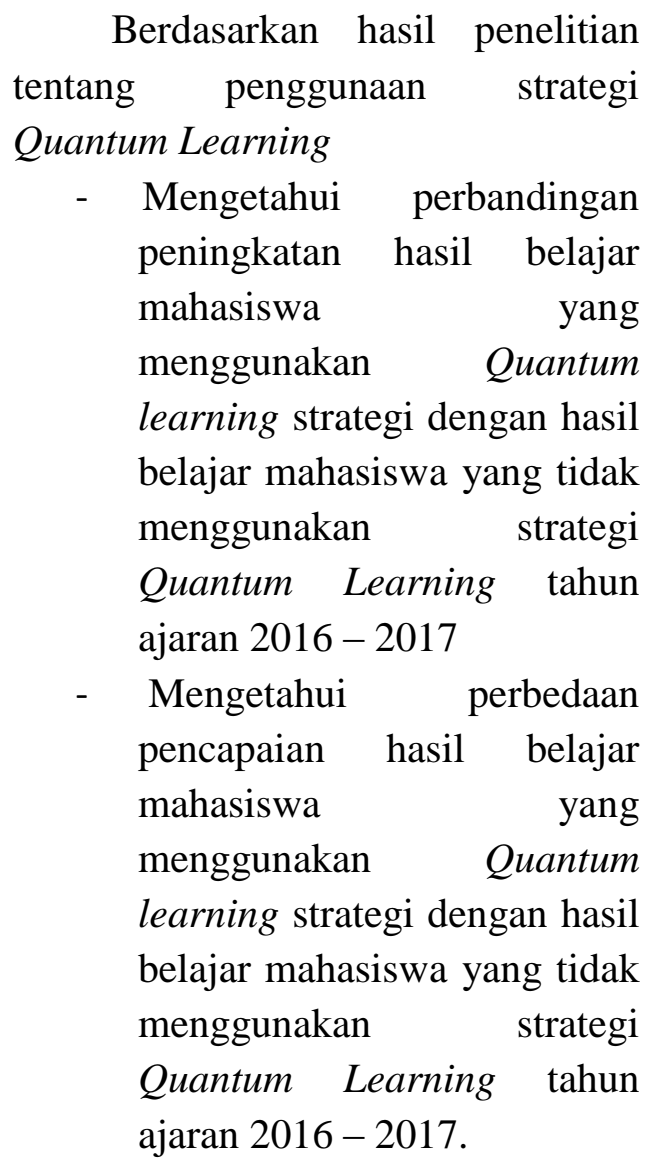

\section{DAFTAR RUJUKAN}

Arikunto, S. 2010. Prosedur Penelitian. Jakarta: Rineka Cipta.
Darwis, dkk. 2011. Terampil Berbahasa. Bandung: Alfabeta.

De Porter, Bobbie, Mark Readrdon, and Sarah Singer Nourine. 2004. Quantum Teaching. Mempraktikkan Quantum Learning di Ruang - ruang Kelas. Bandung: Kaifa.

De Porter, Bobbie and Mike Hernacki. 2003. Quantum Learning: Membiasakan Belajar Nyaman dan Menyenangkan. Bandung : Kaifa.

Freeman, Dianne, Larsen. 2002. Techniques and principle in language teaching. Oxford : Oxford University Press.

Harmer, Jeremy. 2003. The practice of English Language Teaching. Londodn : Longman.

Slamet, S. Y. 2008. Dasar-dasar Pembelajaran Bahasa dan Sastra Indonesia di Sekolah Dasar. Surakarta: UNS Press.

Solehan, T. W, dkk. 2008. Pendidikan Bahasa Indonesia di $S D$. Jakarta: Universitas Terbuka

Sudjono, A. 2010. Pengantar Statistik Pendidikan. Jakarta: RajaGrafindo Persada.

Syah, M. 2008. Psikologi Pendidikan dengan Pendekatan Baru. Bandung: Remaja Rosdakarya. 